\title{
RECENT STATE OF PHYSICAL DEVELOPMENT OF THE JAPANESE CHILDREN
}

\author{
By KIYOSHI SAITO AND RIICHI KAWAKAMI \\ The Institute of Public Health, Tokyo
}

\section{Physical Development of the Infants and the Pre-School Children.}

A study of the weights and heights of 24,708 infants and pre-school children.

1. To determine the recent state of physical development of the infants and the pre-school children in this country, much material was reviewed and selection of records was made. This material $l_{c}$ was collected during a series of field investigations made by the staff of the Institute of Public Health and their co-workers during the period from October, 1940, to September, 1942. This present report is a part of the results of the study and presents some of the tables from the statistical analysis of the measurements of weight and height of 24,708 infants and pre-school children. This group of the children ranges in age from 1 to 6 years inclusive, and physical examinations were made on all the children included in this group except those who were ill in bed. The children observed in the study came from various rural areas, towns and cities of moderate and large size which are scattered throughout the country in twenty-nine prefectures; so that there would be representations from various types of districts and geographic locations throughout the country.

2. In Table 1, the distribution according to age is approximately the same for the two sexes.

3. Measurements of weight and height of new-born infants were made at birth. The differences between the means of the sexes were not great at a given age period in the children, but they are significant as shown in Table 2 .

4. In Table 3 , the averages at each age from 1 to 6 years show that the boys are always taller and heavier than girls. Because all children under the age of 6 years in the selected districts were included, mean weights and heights are somewhat smaller than expected. Consequently the means for supposedly healthy children may be larger than these figures.

5. In Table 4, the relations of weight to height is expressed in the form of a ratio of weight to height at each age. For males in each age group the ratio of the mean weight to mean height exceeds those for females. The ratios of mean weight to mean height for both sexes increase with the age.

6 . In Table 5 , the variations of the rate of increase are expressed numerically. There is a relatively faster increase in weight than in height which suggests that the weightheight index increases as the child grows older. There is little difference in percentage increases either in weight or height for the sexes. It is noticed that the increase in weight and height for both sexes shows clearly an accelerating rate up to the age of 3 years in the weight figures and of 2 years in height figures respectively and slight 
decreases with the following ages.

7. In Table 6, the standard deviations in weight and height in each age period for males and females and the corresponding coefficients of variability are given. It is noticed that coefficients of variability of both weight and height for children under 1 year of age in both sexes are markedly large as compared with those in the succeeding age groups. The coefficients of variability of weight and height are, in general, are irregular with respect to age.

Table 1. Distribution according to sex and age of pre-school children observed for weight and height.

\begin{tabular}{c|r|r|r|r}
\hline \multirow{2}{*}{ Age } & \multicolumn{2}{|c|}{ Number } & \multicolumn{2}{c}{ Per cent. } \\
\cline { 2 - 5 } & Boys & Girls & Boys & Girls \\
\hline All ages & 11.922 & 11.003 & & \\
New-born & 2.092 & 1.893 & 17.5 & 17.2 \\
Under 1 (month) & 134 & 121 & 1.1 & 1.1 \\
$1-2$ & 150 & 85 & .1 .3 & 0.8 \\
$2-3$ & 191 & 171 & 1.6 & 1.6 \\
$3-4$ & 239 & 223 & 2.0 & 2.0 \\
$4-5$ & 245 & 271 & 2.1 & 2.5 \\
$5-6$ & 348 & 287 & 2.9 & 2.6 \\
$6-7$ & 303 & 302 & 2.5 & 2.7 \\
$7-8$ & 327 & 284 & 2.7 & 2.6 \\
$8-9$ & 268 & 268 & 2.2 & 2.4 \\
$9-10$ & 269 & 222 & 2.3 & 2.0 \\
$10-11$ & 253 & 214 & 2.1 & 1.9 \\
$11-12$ & 268 & 193 & 2.2 & 1.8 \\
\hline $1-2$ (year) & 1667 & 1571 & 14.0 & 14.3 \\
$2-3$ & 1183 & 1123 & 9.9 & 10.2 \\
$3-4$ & 1225 & 1207 & 10.3 & 11.0 \\
$4-5$ & 1403 & 1281 & 11.8 & 11.6 \\
$5-6$ & 1357 & 1287 & 11.4 & 11.7 \\
\hline
\end{tabular}

(The Institute of Public Health, Tokyo)

Table 2. Mean weights and heights of infants and pre-school children at the each month for the children under one year and at each year for the children over one year, compared for boys and girls.

\begin{tabular}{c|c|c|c|c}
\hline \multirow{2}{*}{ Age } & \multicolumn{2}{|c|}{ Weight $(\mathrm{kg})$} & \multicolumn{2}{c}{. Height $(\mathrm{cm})$} \\
\cline { 2 - 5 } & Boys & Girls & Boys & Girls \\
\hline New-born & 3.05 & 2.99 & 50.2 & 49.3 \\
Under 1 month & 3.22 & 3.22 & 50.2 & 49.7 \\
$1-2$ & 4.38 & 4.19 & 54.8 & 54.6 \\
$2-3$ & 5.39 & 5.04 & 58.7 & 57.6 \\
$3-4$ & 5.97 & 5.49 & 60.8 & 59.5 \\
$4-5$ & 6.45 & 5.98 & 62.9 & 61.5 \\
\hline
\end{tabular}




\begin{tabular}{c|c|c|c|c}
\hline \multirow{2}{*}{ Age } & \multicolumn{2}{|c|}{ Weight $(\mathrm{kg})$} & \multicolumn{2}{c}{ Height $(\mathrm{cm})$} \\
\cline { 2 - 5 } & Boys & Girls & Boys & Girls \\
\hline $5-6$ & 6.72 & 6.33 & 64.4 & 63.1 \\
$6-7$ & 7.21 & 6.76 & 66.0 & 64.3 \\
$7-8$ & 7.40 & 6.99 & 67.1 & 66.2 \\
$8-9$ & 7.44 & 7.17 & 67.8 & 66.9 \\
$9-10$ & 7.80 & 7.44 & 69.3 & 68.1 \\
$10-11$ & 7.91 & 7.65 & 70.2 & 69.4 \\
$11-12$ & 8.10 & 7.60 & 70.9 & 69.7 \\
\hline Under 1 year & 6.70 & 6.44 & 64.7 & 63.7 \\
$1-2$ & 9.17 & 8.79 & 75.9 & 74.7 \\
$2-3$ & 11.53 & 11.01 & 84.5 & 83.3 \\
$3-4$ & 13.31 & 12.82 & 91.3 & 90.2 \\
$4-5$ & 14.97 & 14.28 & 97.5 & 96.3 \\
$5-6$ & 16.23 & 15.83 & 103.1 & 102.2 \\
\hline
\end{tabular}

(The Institute of Public Health, Tokyo)

Table 3. Comparison of the mean weights and heights, showing the excess of boys at different ages.

\begin{tabular}{c|c|c|c|c}
\hline \hline \multirow{2}{*}{ Age (years) } & \multicolumn{4}{|c}{ Excess in the mean- } \\
\cline { 2 - 5 } & \multicolumn{2}{|c|}{ Weight of- } & \multicolumn{2}{c}{ Height of - } \\
\cline { 2 - 5 } & $\begin{array}{c}\text { Boys over } \\
\text { girls (kg) }\end{array}$ & $\begin{array}{c}\text { Boys (taking } \\
\text { girls as 1.0) }\end{array}$ & $\begin{array}{c}\text { Boys over } \\
\text { girls (cm) }\end{array}$ & $\begin{array}{c}\text { Boys (taking } \\
\text { girls as 1.0) }\end{array}$ \\
\hline Under 1 & 0.35 & 1.05 & 1.0 & 1.01 \\
$1-2$ & .38 & 1.04 & 1.2 & 1.01 \\
$2-3$ & .52 & 1.04 & 1.2 & 1.01 \\
$3-4$ & .49 & 1.03 & 1.1 & 1.01 \\
$4-5$ & .69 & 1.04 & 1.2 & 1.01 \\
$5-6$ & .40 & 1.02 & .9 & 1.00 \\
\hline
\end{tabular}

(The Institute of Public Health, Tokyo)

Table 4. The ratios of mean weight to mean height of infants and pre-school children at each age, compared for boys and girls.

\begin{tabular}{c|c|c}
\hline & \multicolumn{2}{|c}{ Mean weight in $\mathrm{g}$} \\
\cline { 2 - 3 } & \multicolumn{2}{|c}{ Mean height in cm } \\
\hline Under 1 & Boys & Girls \\
$1-2$ & 104 & 101 \\
$2-3$ & 120 & 117 \\
$3-4$ & 136 & 131 \\
$4-5$ & 145 & 141 \\
$5-6$ & 151 & 147 \\
\hline
\end{tabular}

(The Institute of Public Health, Tokyo) 
Tab'le 5. Percentage of annual increase in mean weight and height of infants and pre-school children, compared for boys and girls.

\begin{tabular}{c|c|c|c|c}
\hline \hline \multirow{2}{*}{ Age period } & \multicolumn{4}{|c}{ Percentage increases in - } \\
\cline { 2 - 5 } & \multicolumn{3}{|c|}{ Weight } & \multicolumn{2}{c}{ Height } \\
\cline { 2 - 5 } & Boys & Girls & Boys & Girls \\
\hline Under 1 & 35.0 & 36.4 & 15.6 & 17.3 \\
$1-2$ & 25.7 & 25.2 & 11.3 & 11.5 \\
$2-3$ & 15.4 & 16.4 & 8.3 & 8.2 \\
$3-4$ & 12.4 & 11.3 & 6.9 & 6.7 \\
$4-5$ & 8.4 & 10.8 & 5.7 & 6.1 \\
$5-6$ & 5 & & & \\
\hline
\end{tabular}

(The Institute of Public Health, Tokyo)

Table 6. Variation in weights and heights of boys and girls of the same age.

\begin{tabular}{|c|c|c|c|c|}
\hline \multirow{2}{*}{ Age } & \multicolumn{2}{|c|}{ Standard deviation } & \multicolumn{2}{|c|}{ Coefficient of variability } \\
\hline & Boys & Girls & Boys & Girls \\
\hline & \multicolumn{4}{|c|}{ Weight } \\
\hline Under 1 & 15.7 & 16.2 & 22.3 & 25.2 \\
\hline $1-2$ & 13.3 & 12.5 & 12.3 & 12.8 \\
\hline $2-3$ & $14: 5$ & 13.4 & 12.7 & 12.3 \\
\hline $3-4$ & 14.4 & 14.2 & 10.7 & 11.1 \\
\hline $4-5$ & 14.3 & 16.1 & 9.6 & 11.3 \\
\hline \multirow[t]{2}{*}{$5-6$} & 17.5 & 17.2 & 10.8 & 11.1 \\
\hline & \multicolumn{4}{|c|}{ Height } \\
\hline Under 1 & 6.0 & 5.6 & 9.3 & 8.9 \\
\hline $1-2$ & 4.1 & 4.0 & 5.5 & 5.4 \\
\hline $2-3$ & 4.3 & 4.4 & 5.1 & 5.3 \\
\hline $3-4$ & $4: 1$ & 4.4 & 4.5 & 4.8 \\
\hline $4-5$ & 4.5 & 4.7 & 4.6 & 4.9 \\
\hline $5-6$ & 4.7 & 4.8 & 4.5 & 4.7 \\
\hline
\end{tabular}

(The Institute of Public Health, Tokyo)

II. Growth of the School Children During the WaR.

It has been known that during a war there is some deterioration of the health conditions of the nation involved, and, obviously, improper and insufficient food is the major cause.

In order to confirm the result of prolonged underfeeding of children during the war years, a statistical investigation of weight and height of school children was made. This material was obtained by the physical examination which had been done before and following the war.

In the report from the Ministry of Education it is found that the mean weight and 
height of school children has been increasing since the years before the war. The present study, therefore, deals with the growth of the children during the entire school life instead of the absolute measurements. The children were selected from ten schools in each of six prefectures throughout the country in order to be representative of districts and geographic localities. Two different groups in each school were observed, the first group of children being those graduated in 1937, the year of the outbreak of the war, and the second group of children being those graduated in 1945, the year of the termination of the war.

The results obtained from the study were summarized as follows: During the war, the growth of weight and height of school children in the urban areas had been markedly disturbed while those of the rural areas showed no change or even increase in weight and height when these two groups were compared as indicated in the table. This disparity provides marked evidence of the effect of food and healthful mode of life in the country during the war as compared with the marked food shortage and difficulty of living in the city during the same period.

Comparison of growth of the children before and during the war is more clearly shown by means of graphical presentation in a space as given in the figure taking atge in the $\mathrm{Y}$ axis, time in the $\mathrm{X}$ axis and measurement in the $\mathrm{Z}$ axis.

The lines $A B$ and $C D$ represent the trend of growth of the children before and during the war respectively, and $\mathrm{AC}$ and $\mathrm{BD}$ represent the trend of measurement of the children before and during the war respectively.

The lines $\mathrm{AB}$ and $\mathrm{CD}$ may be projected on the $\mathrm{YZ}$ plane instead of in a space; and in case the lines $A B$ and $C D$ approach or cross each other, there is indication of some unfavorable influence upon the growth of the children.

Table 7. Comparison of the increment of mean weights and heights of boys and girls before and during the war, for urban and rural district in each of 6 Prefectures.

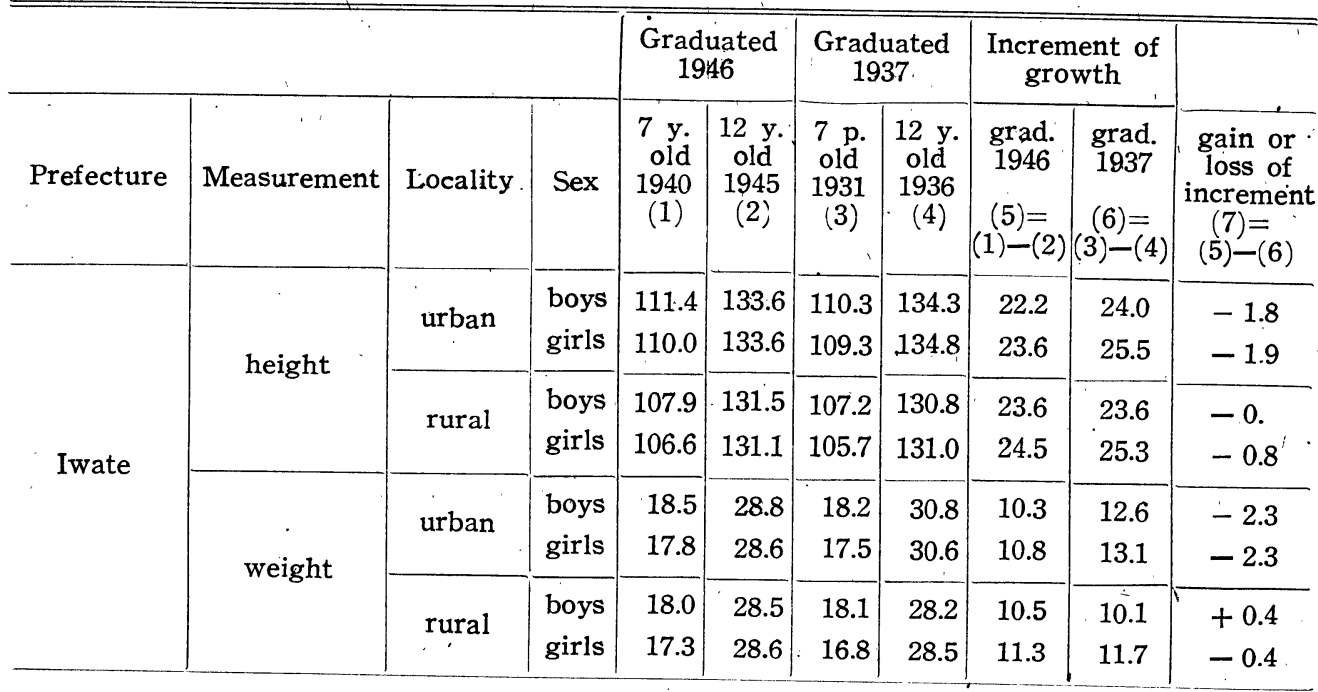




\begin{tabular}{|c|c|c|c|c|c|c|c|c|c|c|}
\hline \multirow[b]{2}{*}{ Prefecture } & \multirow[b]{2}{*}{ Measurement } & \multirow[b]{2}{*}{ Locality } & \multirow[b]{2}{*}{ Sex } & \multicolumn{2}{|c|}{$\begin{array}{l}\text { Graduated } \\
\quad 1946\end{array}$} & \multicolumn{2}{|c|}{$\begin{array}{c}\text { Graduated } \\
\quad 1937 \\
\end{array}$} & \multicolumn{2}{|c|}{$\begin{array}{l}\text { Increment of } \\
\text { growth }\end{array}$} & \multirow[b]{2}{*}{$\begin{array}{c}\text { gain or } \\
\text { loss of } \\
\text { increment } \\
(7)= \\
(5)-(6)\end{array}$} \\
\hline & & & & $\begin{array}{c}7 \mathrm{y} . \\
\text { old } \\
1940 \\
(1)\end{array}$ & $\begin{array}{c}12 \mathrm{y} . \\
\text { old } \\
1945 \\
(2)\end{array}$ & $\begin{array}{c}7 \text { y. } \\
\text { old } \\
1931 \\
(3)\end{array}$ & $\begin{array}{c}12 \mathrm{y} . \\
\text { old } \\
1936 \\
(4)\end{array}$ & $\begin{array}{c}\text { grad. } \\
1946 \\
\\
(5)= \\
(1)-(2)\end{array}$ & $\left|\begin{array}{c}\text { grad. } \\
1937 \\
(6)= \\
(3 ;-(4)\end{array}\right| i$ & \\
\hline \multirow{7}{*}{ Saitama } & \multirow{3}{*}{ height } & \multirow[t]{2}{*}{ urban } & boys & 110.3 & 131.9 & 110.0 & 134.3 & 21.6 & 24.3 & -2.7 \\
\hline & & & giris & 109.2 & 131.4 & 107.6 & 133.7 & & & \\
\hline & & rural & $\begin{array}{l}\text { boys } \\
\text { girls }\end{array}$ & $\begin{array}{l}107.8 \\
106.3\end{array}$ & $\begin{array}{l}131.6 \\
130.9\end{array}$ & $\begin{array}{l}107.5 \\
106.0\end{array}$ & $\begin{array}{l}131.5 \\
130.7\end{array}$ & $\begin{array}{l}23.8 \\
24.6\end{array}$ & $\begin{array}{l}24.0 \\
24.7\end{array}$ & $\begin{array}{l}-0.2 \\
-0.1\end{array}$ \\
\hline & \multirow{4}{*}{ weight } & \multirow{2}{*}{ urban } & boys & 18.4 & 28.3 & 18.2 & 29.0 & 9.9 & 10.8 & -09 \\
\hline & & & girls & 17.7 & 27.8 & 17.4 & 28.4 & 10.1 & 11.0 & -0.9 \\
\hline & & \multirow{2}{*}{ rural } & boys & 17.6 & 28.9 & 17.7 & 29.1 & 11.3 & 11.4 & -0.1 \\
\hline & & & girls & 17.1 & 28.4 & 17.0 & 28.3 & 11.3 & 11.3 & -0 \\
\hline \multirow{8}{*}{ Chiba } & \multirow{4}{*}{ height } & \multirow{2}{*}{ urban } & boys & 110.5 & 132.4 & 109.9 & 134.7 & 21.9 & 24.8 & -2.9 \\
\hline & & & girls & $\mid 109.3$ & 133.2 & 108.5 & 135.4 & 23.9 & 269 & -3.0 \\
\hline & & \multirow{2}{*}{ rural } & boys & 109.4 & 131.9 & 108.2 & 132.1 & 22.5 & 23.9 & -1.4 \\
\hline & & & giral & 108.9 & 133.0 & 107.8 & 132.8 & 24.1 & 25.0 & -0.9 \\
\hline & \multirow{4}{*}{ weight } & \multirow{2}{*}{ urban } & boys & 18.6 & 28.7 & 18.3 & 29.9 & 10.1 & 11.6 & -1.5 \\
\hline & & & girls & 18.1 . & 29.4 & 17.8 & 30.6 & 11.3 & 12.8 & -1.5 \\
\hline & & \multirow{2}{*}{ rural } & boys & 18.2 & 28.9 & 18.5 & 29.8 & 10.7 & 11.3 & -0.6 \\
\hline & & & girls & 18.0 & 28.6 & 18.1 & 29.6 & 10.6 & 11.5 & -0.9 \\
\hline \multirow{8}{*}{ Wakayama } & \multirow{4}{*}{ height } & \multirow{2}{*}{ urban } & boys & 111.3 & 130.2 & 109.9 & $\mid 133.4$ & 18.9 & 23.5 & -4.6 \\
\hline & & & girls & 109.9 & 129.9 & 108.4 & 132.9 & 20.0 & 24.5 & -4.5 \\
\hline & & \multirow{2}{*}{ rural } & boys & 110.5 & 132.1 & 109.6 & 134.9 & 21.6 & 25.3 & -3.7 \\
\hline & & & girls & 108.9 & 131.8 & 108.5 & 134.7 & 22.9 & 26.2 & -3.3 \\
\hline & \multirow{4}{*}{ weight } & urban & boys & 18.3 & 26.9 & 18.4 & 30.0 & 8.6 & 11.6 & -3.0 \\
\hline & & urdani & girls & 17.9 & 27.1 & 18.8 & 28.9 & 9.2 & 10.5 & -1.3 \\
\hline & & rural & boys & 18.3 & 28.5 & 18.3 & 30.3 & 10.2 & 12.0 & -1.8 \\
\hline & & Itutat & girls & 17.7 & 28.3 & 18.1 & 30.7 & 10.6 & 12.6 & -2.0 \\
\hline & & urban & boys & 110.5 & 131.9 & $\mid 112.0$ & 133.5 & 21.4 & 21.5 & -0.1 \\
\hline & height & & girls & 110.3 & 131.9 & 109.1 & 134.6 & 21.6 & 25.5 & -3.9 \\
\hline & & rural. & boys & 108.7 & 132.4 & 109.9 & 132.0 & 23.7 & 22.1 & -1.6 \\
\hline Ol-aצnm? & & Hetat & girls & 108.6 & 132.6 & 107.2 & 131.9 & 24.0 & 24.7 & -0.7 \\
\hline 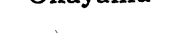 & & Wrhon & boys & 18.8 & 28.5 & 18.2 & 29.5 & 9.7 & 11.3 & -1.6 \\
\hline & & UI Ddil & girls & 17.9 & 28.3 & 18.2 & 30.2 & 10.4 & 12.0 & -1.6 \\
\hline & & rural & boys & 18.2 & 29.3 & 17.5 & 28.4 & 11.1 & 10.9 & -0.2 \\
\hline & & Iural & girls & 17.4 & 30.5 & 17.3 & 28.6 & 13.1 & 11.3 & +1.8 \\
\hline
\end{tabular}




\begin{tabular}{|c|c|c|c|c|c|c|c|c|c|c|}
\hline \multirow[b]{2}{*}{ Prefecture } & \multirow[b]{2}{*}{ Measurement } & \multirow[b]{2}{*}{ Locality } & \multirow[b]{2}{*}{ Sex } & \multicolumn{2}{|c|}{$\underset{1946}{\text { Graduated }}$} & \multicolumn{2}{|c|}{$\begin{array}{c}\text { Graduated } \\
1937\end{array}$} & \multicolumn{2}{|c|}{$\underset{\text { growth }}{\text { Increment of }}$} & \multirow[b]{2}{*}{$\begin{array}{l}\text { gain or } \\
\text { loss of } \\
\text { increment } \\
(7)= \\
(5)-(6)\end{array}$} \\
\hline & & & & $\begin{array}{c}7 \mathrm{y} . \\
\text { old } \\
1940 \\
(1)\end{array}$ & $\mid$\begin{tabular}{c|}
$12 \mathrm{y}$. \\
old \\
1945 \\
$(2)$
\end{tabular} & $\begin{array}{c}7 \text { y. } \\
\text { old } \\
1931 \\
(3)\end{array}$ & $\begin{array}{c}12 \mathrm{y} . \\
\text { old } \\
1936 \\
(4)\end{array}$ & $\begin{array}{l}\text { grad. } \\
1946 \\
(5)= \\
(1)-(2)\end{array}$ & $\begin{array}{c}\text { grad. } \\
1937 \\
(6)= \\
(3)-(4)\end{array}$ & \\
\hline \multirow{4}{*}{ Kumamoto } & \multirow{2}{*}{ height } & urban & $\begin{array}{l}\text { boys } \\
\text { girls }\end{array}$ & $\begin{array}{l}110.7 \\
109.7\end{array}$ & \begin{tabular}{|l|}
131.8 \\
131.9 \\
\end{tabular} & $\begin{array}{l}109.3 \\
109.3\end{array}$ & $\begin{array}{l}136.1 \\
136.5\end{array}$ & $\begin{array}{l}21.1 \\
22.2\end{array}$ & $\begin{array}{l}26.8 \\
27.2\end{array}$ & $\begin{array}{l}-5.7 \\
-5.0\end{array}$ \\
\hline & & rural & $\begin{array}{l}\text { boys } \\
\text { girls }\end{array}$ & $\begin{array}{l}107.7 \\
106.7\end{array}$ & $\begin{array}{l}132.1 \\
132.5\end{array}$ & $\begin{array}{l}108.0 \\
108.5\end{array}$ & $\begin{array}{l}133.4 \\
132.6\end{array}$ & $\begin{array}{l}23.4 \\
25.6\end{array}$ & $\begin{array}{l}25.4 \\
24.1\end{array}$ & $\begin{array}{l}-2.0 \\
-1.5\end{array}$ \\
\hline & \multirow{2}{*}{ weight } & urban & $\begin{array}{l}\text { boys } \\
\text { girls }\end{array}$ & $\begin{array}{l}18.7 \\
18.1\end{array}$ & $\begin{array}{l}28.7 \\
28.7\end{array}$ & $\begin{array}{l}18.2 \\
17.6\end{array}$ & $\begin{array}{l}29.8 \\
30.8\end{array}$ & $\begin{array}{r}\cdot 10.0 \\
10.6\end{array}$ & $\begin{array}{l}11.6 \\
13.2\end{array}$ & $\begin{array}{l}-1.6 \\
-2.6\end{array}$ \\
\hline & & rural & $\begin{array}{l}\text { boys } \\
\text { girls }\end{array}$ & $\begin{array}{r}-18.4 \\
-18.4\end{array}$ & $\begin{array}{l}29.3 \\
30.6\end{array}$ & $\begin{array}{l}17.5 \\
17.7\end{array}$ & $\begin{array}{l}29.5 \\
29.2\end{array}$ & $\begin{array}{l}10.9 \\
12.6\end{array}$ & $\begin{array}{l}12.0 \\
11.5\end{array}$ & $\begin{array}{r}-1.6 \\
+1.1\end{array}$ \\
\hline
\end{tabular}

Graphic presentation in a space of the increase in weight, as indicated before and during the war.

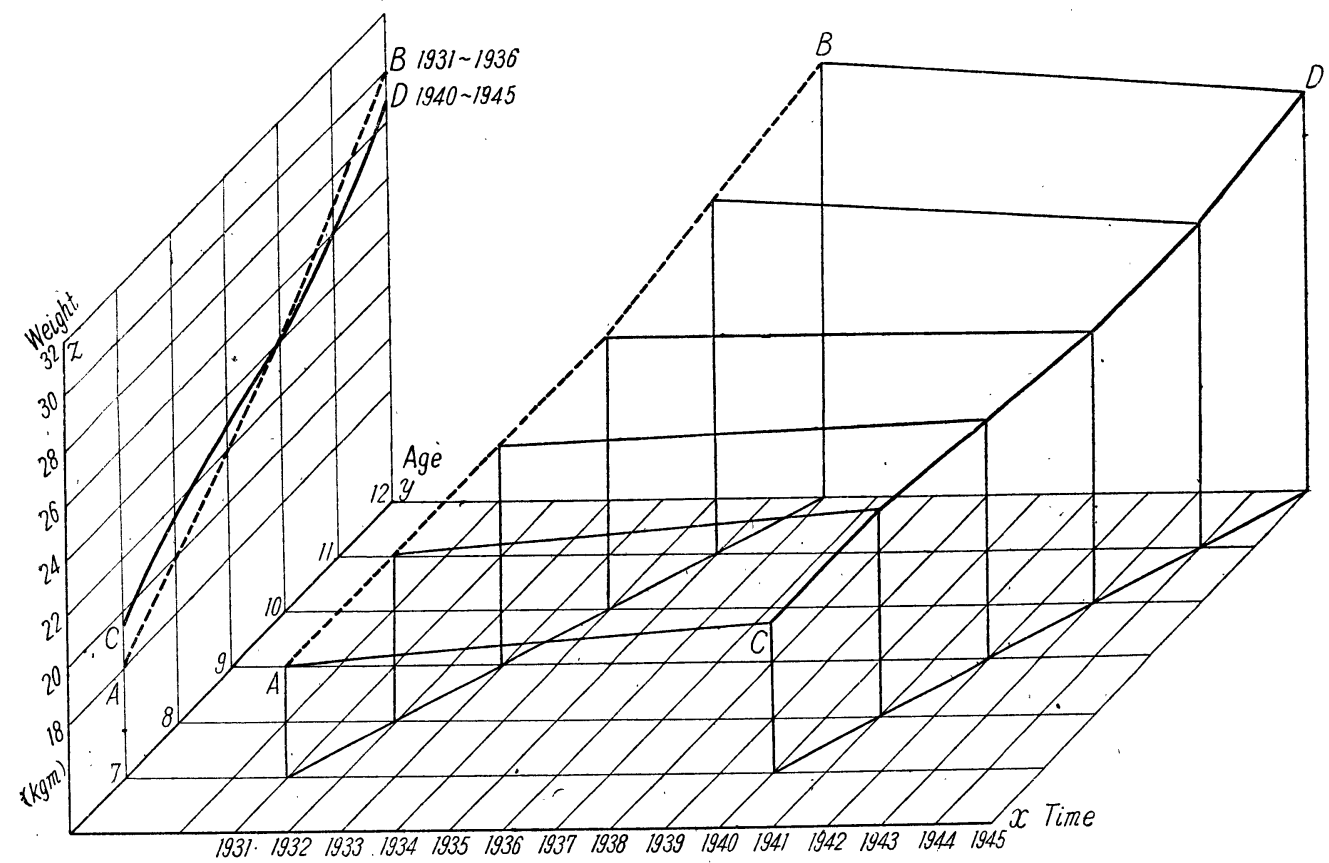

